DOI 10.7251/SCMED1802083T UDC 616.858-008.6-02 COBISS.RS-ID 7836440

\title{
The Importance of Rehabilitation Treatment in Patients with Parkinson's Disease
}

\section{SUMMARY}

Parkinson's disease (PD) is a chronic neurodegenerative disease with a slowly progressive course, having an average duration of about 15 years. It is characterized by akinesia/ bradykinesia, tremor, rigidity and postural instability. For the diagnosis of PD at least two of these four characteristics are required. There is a whole spectrum of non-motor symptoms (mood disorders, different levels of cognitive deficit, sleep disorders, fatigue, autonomic dysfunction). The patomorphologic base of PD is a disorder of the nigrostriatal dopaminergic mechanisms, metabolic damages, structural changes (hydrocephalus, tumors) or degenerative processes of presynaptic nigrostriatal dopaminergic projections or the striatum. Although the pharmacological approach is still essential, more systematic reviews and metaanalysis support the hypothesis on the positive effects of physiotherapy and intensive kinesiotherapy in PD patients. The main rehabilitation method for these patients is kinesiotherapy in its various forms, related to the individual therapeutic target, based on functional limits. Rehabilitation programs contain kinesiotherapeutic procedures for balance, posture, the range of motions- especially rotation of the trunk, strength, elongation, as well as exercise for functionally reduced motion types. The greatest emphasis in the rehabilitation process should be on the re-education of gait, which involves the optimization of initiation, speed, and length of steps. The aim of kinesiotherapy and occupational therapy is to bring the maximum functional independence of the patient and the occurrence of complications to a minimum.

In neurodegenerative disorders, all modalities for improving the gait function are essentially a lifelong activity. Therapeutic strategy comes down to the combination of pharmacotherapy and neurorehabilitation methods.

Key words: Parkinson's disease, neurorehabilitation, gait.

Teodora Talić, Tatjana Bućma ${ }^{1,2}$, Olivera PilipovićSpasojević, Luka Talić ${ }^{2}$

${ }^{1}$ Institute for Physical Medicine and Rehabilitation "Dr Miroslav Zotović”, Banja Luka

${ }^{2}$ Faculty of Medicine, University of Banja Luka, Banja Luka, Republic of Srpska, Bosnia and Herzegovina

Manuscript received: June $17^{\text {th }}, 2018$ Manuscript accepted: November $19^{\text {th }}, 2018$ 


\section{Definition and patophysiological basis of Parkinson's disease}

Parkinsonism is a clinical syndrome characterized by akinesia/ bradykinesia, tremor, rigidity and postural instability. For the diagnosis of this syndrome at least two of these four characteristics are required. Patomorphological basis of this syndrome is a disorder of nigrostriatal dopaminergic mechanisms, whether it comes to the discharge of synapses (reserpine, tetrabenazine), to the block the dopamine receptors in the striatum (neuroleptics), metabolic damages, the structural changes (hydrocephalus, tumors) or degenerative processes of the presynaptic nigrostriatal dopaminergic projections or the striatum itself. ${ }^{1}$

Accordingly, parkinsonism is classified as a primary, idiopathic Parkinson's disease (PD), secondary or symptomatic, so-called "parkinsonism- plus" syndromes, parkinsonism within the neurodegenerative disease, and psychogenic parkinsonism. $^{2}$

PD is a chronic neurodegenerative disease with a slowly progressive course, with an average duration of about 15 years. This is the second most common neurodegenerative disease, right after Alzheimer's disease, and certainly the most common form of parkinsonism. In about $75 \%$ of cases of parkinsonism, the idiopathic form of Parkinson's disease is present. ${ }^{3,4}$

It is believed that Parkinson's disease affects $0.3 \%$ of the world population. Based on the data of the European Association of Parkinson's disease 6.3 million people worldwide suffer from PD, but when it comes to Europe, available statistical data show the number of 1.2 million patients. The incidence and prevalence increase exponentially with age so after 65 years of age $1 \%$ of people have Parkinson's disease. ${ }^{3,4}$

The onset of PD can be observed at any age- rarely before 30 years of age, in 5-10\% the onset occurs before 50 years of age, and in $50 \%$ before 65 years of age. Most commonly the disease starts after 60 years of age, and with a higher incidence in men (ratio of men and women 3:2).5,6

Clinically, the motor symptoms of PD appear when 60$80 \%$ of striatal dopaminergic terminals and $40-50 \%$ of the neurons in substantia nigra- pars compacta are lost. The observation that a massive dopaminergic denervation occurs before the early symptoms of PD is explained by the compensatory presynaptic and postsynaptic mechanisms in nigrostriatal dopaminergic system. ${ }^{7}$

Three basic pathological findings in PD include:

1. The loss of dopaminergic neurons in the pars compacta of the substantia nigra (loss of $50 \%$ of these neurons causes the expression of the motor symptoms of the disease); the extinction of these neurons in patients with PD is 8-10 times faster than during normal aging and is most prominent in the first five years of the disease. It is considered to achieve the plateau after ten years of the disease duration. The degeneration of mesolimbic pathway leads to mood disorder, while the degeneration of mesocortical pathway leads to cognitive disorder. Progressive neurodegeneration also affects the nondopaminergic neurons with a consequent deficit of other neurotransmitters besides dopamine, such as serotonin, noradrenaline, acetylcholine, and the manifestation of a whole series of symptoms such as mood and behavioral disorders, cognitive disorders. ${ }^{8}$

2. Reduced levels of dopamine in the striatum, especially at the level of the putamen, where nigrostriatal fibers project (with a reduction of over $80 \%$ of normal values). ${ }^{9}$

3. Lewy neurites and Lewy bodies are intracellular protein inclusions, with alpha-synuclein as their base, which is in physiological conditions present in a significant concentration at the level of the neurons and is related to the normal function of synapses and the processes that are relevant to neurodegeneration. It is assumed that there is a problem with the processing of this protein which, when found in appropriate circumstances, shows a strong tendency to form aggregates (Lewy bodies). ${ }^{10}$

In most cases, a sporadic or idiopathic PD is present, and age is the only defined risk factor for its occurrence, whereas $10-20 \%$ of involved patients have a genetic (autosomal dominant and recessive) form of PD. ${ }^{11}$ domain.

\section{The clinical presentation of Parkinson's disease}

Characteristic clinical features of Parkinson's disease involve the presence of motor symptoms of the disease and a whole range of non-motor manifestations. ${ }^{12,13}$ Non-motor symptoms in PD include mood disorders (primarily apathy, depression and anxiety); various degree of cognitive decline (from the level of mild cognitive impairment to dementia); and various forms of sleep disorders (sleep fragmentation, REM sleep disorders, sleep apnea, excessive daytime sleepiness); sensory disturbances (pain, dysesthesia); fatigue, autonomic dysfunction (constipation, urinary problems, sexual dysfunction, temperature dysregulation, orthostatic hypotension, profound sweating). ${ }^{14}$ 
In the comprehensive understanding of the PD symptoms, it was observed that motor signs in the PD were often preceded or were associated with non-motor symptoms.

\subsection{Clinical forms of Parkinson's disease}

Clinical forms of the PD include tremor and non-tremor form of the disease: akinetic-rigid form and a form with postural instability and gait disorder (Postural Instability Gait Disorder- PIGD), as well as the mixed form of the PD. ${ }^{15}$ Generally, hyperkinetic form of PD is characterized by a worse response to applied levodopa, but has a slower course and progression. In contrast, in the case of a hypokinetic form of the disease, the response to the therapy is better, but there is a faster progression of the disease with the occurrence of dementia, and psychiatric complications of the therapy at an earlier age. ${ }^{16}$

\subsection{Motor symptoms of Parkinson's disease}

The cardinal symptoms of the disease are motor symptoms, which include tremor, rigidity, and bradykinesia; usually in the later stages of the disease there is a development of postural instability. ${ }^{17}$

Tremor is the strongest predictor of $\mathrm{PD}$ and it is a resting tremor, most often in combination with the postural or kinetic tremor of extremities, primarily distally. It is present in approximately half of the patients; in $69 \%$ of patients, tremor is an initial sign of the disease, although about $15 \%$ of patients with PD never develop tremor during the course of the disease. Tremor does not have to get worse during the disease and about $9 \%$ of patients lose tremor during the disease. Tremor is not considered as a pure dopaminergic sign and severity of its manifestations does not correlate with dopamine deficiency in the striatum, and it is different and often has a quite disappointing response to levodopa and dopamine agonists. ${ }^{18}$

Bradykinesia is the most cardinal symptom of Parkinson's disease. It represents the slowness in initiating of voluntary movements and the progressive reduction of the speed and amplitude of the same, repetitive movements. The severity of clinical manifestations of bradykinesia correlates with the degree of nigrostriatal damage. It changes in conditions such as stress or sudden stimuli, which indicates the preservation of motor programs that can not be otherwise run except as a reaction to the external stimuli. ${ }^{18}$

Rigidity is muscle hypertonia, which manifests both proximally and distally, affecting evenly agonistic and antagonistic muscles. It is present in more than $90 \%$ of the patients with PD and correlates to the deficit of dopamine in the striatum. ${ }^{18}$

Postural instability, due to the loss of postural reflexes, is usually manifested in the later stages of the PD, usually not prior to the third stage according to Hoehn and Yahr classification. However, in early stages of PD patients have a lower stability limit of the body which is referred to as compensated intraclinical postural instability.

In addition to these cardinal motor symptoms, during the course of the disease a whole range of other motor manifestations of PD appear in the form of gait disturbances and falls, positional deformities, and also disorders of speech and swallowing. ${ }^{19}$

\subsubsection{Gait abnormalities in Parkinson's disease}

Gait abnormalities (reduced speed, shortened length of the step, reluctance prior to the start of stepping, a longer period of relying on both feet) are an integral part of the clinical manifestations of Parkinson's disease and significantly disable a patient and determine the poor quality of life. ${ }^{20}$ In addition, the disorder of rhythmicity of the gait is manifested, the inconsistency of the locomotor form, with a marked variability in length and time duration of the step ("stride-to-stride variability"), which is considered to be a parameter of a higher risk of falls. Problems are particularly pronounced while the patient turns, caused by axial rigidity and lack of intersegment flexibility, where patients turn as a block that often leads to falls. ${ }^{21}$ Parkinson's gait is slowed, with reduced step length during the gait cycle, decreased cadencethe number of steps per minute, and on the other hand, there is an extended period of stride in contact phase. ${ }^{22}$ Ranges of motions in hips, knees, and ankles are reduced mainly due to the rigidity and reduced extension in the joint. The swinging of arms is significantly reduced or not present at all, trunk rotation is carried out in a block with the pelvis. Patients stand with pronounced flexion of the spine and neck, moderate flexion of elbows and slightly flexed feet. The position of generalized flexion is often more pronounced during walking.

A huge problem in gait are blocking episodes of "freezing" in gait, especially when turning and encountering obstacles, walkways and entrances. ${ }^{22}$

Initiation of gait includes the period of preparation for the movement and execution phase of the movement. In PD patients, preparation time is significantly prolonged, with a tendency for further extension as the disease progresses. The execution phase of the movement is also extended but to a lesser extent. ${ }^{23}$ During initiation, walking posture is adjusted by moving the center of 
gravity, which is achieved when moving the center of gravity towards the front by flexion of the trunk and ankle. In PD patients, particularly in advanced stages, the move of the center of mass-gravity is slowed. ${ }^{24}$ In addition to the slowdown in the front adjustment of the center of the mass, there is a reduced lateral shift of the body mass over the stance limb, decreased propulsive forces and prolonged anticipatory postural adjustments. Length of the step can become normal when using visual guides and auditory rhythms, also the walk performance deteriorates when there is a distracting task during walk. ${ }^{25,26}$

Festination is the disturbance in gait pattern typical for $\mathrm{PD}$, and less frequently seen in parkinsonism. The main characteristics are fast, small steps in an attempt to keep the center of gravity between the foot while the trunk is reluctantly leaning forward, with the center of gravity shifted forward. In order to compensate the instability and prevent the fall, patient increases the speed of walking and shortens the stride length. ${ }^{27,28}$

PD characteristically starts asymmetrically, first affecting one side of the body, on which signs of the disease are more prominent throughout the duration of the disease. In the further course, there is a disturbance of posture, followed by the progression on the other side of the body, whereas in the later stages postural reflexes are also affected, followed by postural instability. At the end, the patient becomes severely physically disabled, confined to a wheelchair or bed.

\section{Clinical assessment of PD}

Stage of the disease is determined based on the scale of Hoehn and Yahra ${ }^{29}$, which primarily described five stages of the disease, and later was modified with additional stages 1.5 and 2.5 of the disease. Stage 1: disease affects one side of the body; Stage 1.5: The single-sided plus axial involvement; stage 2: Bilateral disease without any disturbance of the balance; Stage 2.5: Mild bilateral disease with recovery on pull test; stage 3: Mild to moderate bilateral disease; some postural instability; physically independent; Stage 4: Severe disability; still able to walk or stand unassisted; Stage 5: Wheelchairbound or bedridden. According to this scale, stage 3 is considered critical (loss of balance) and indicates a worse prognosis, significantly higher risk for dementia and death.

The severity of PD is estimated on The unified Parkinson's disease rating scale (UPDRS). ${ }^{30}$ This scale consists of four sub-scales: the first one estimates thinking, mood and behavior, the second is related to the daily activities, the third presents a motor overview of parkinsonism symptoms, while the fourth estimates complications of PD therapy. A higher sum of values of these scales corresponds to the worse clinical symptoms of the disease.

For the purpose of behavioral assessment and determination of the most common disorders of mood and behavior, Hamilton anxiety rating scale and Hamilton rating scale for depression are used.

Hamilton Anxiety Rating Scale (HAM-A) ${ }^{31}$ is a scale with 14 items, which enables estimation of psychical and somatic anxiety: 13 questions and an observation by the examiner on the behavior of the patient during the test, and the scoring of each response to the scale of zero to four, where a higher score indicates a higher degree of manifested anxiety. The total score ranges from o to 56: mild anxiety- total score $=18$, moderate anxiety - total score $=25$ and severe anxiety - total score $=30$.

Hamilton Rating Scale for Depression (HRSD), also known as HDRS or HAM-D ${ }^{32}$, is used to determine the severity of manifested depression. The original version consists of 17 items (HDRS17). A total score implies: 0-7 $=$ no depression; 8-15 $=$ minor depression and score 10 or more $=$ major depression .

In order to assess cognitive impairment, the Mini-Mental test (MMSE) ${ }^{33}$ and the Clinical scale for the assessment of dementia are used. Mini-mental test in standard form (MMSE) was defined by Folstein in 1975 and it is a short structured test, which can be applied for an initial evaluation of the cognitive status of the patient, as well as for its further cognitive monitoring. It includes the interview with the patient and examines the functions, including arithmetic, memory and orientation (temporal and spatial orientation), attention, comprehension, speech understanding, reading, writing, drawing, and arithmetics. The score implies: 30-27 = cognition maintained; 26-24 = mild cognitive disorder; 23-18 $=$ mild dementia $; 17-11=$ moderate dementia $; 0-10=$ severe dementia.

Clinical dementia rating scale (CDR $)^{34}$ includes scoring of six cognitive domains: memory, orientation, evaluation and problem-solving skills, social role, hobbies, and the possibility of keeping an account of themselves. The final score is computed by an algorithm and is assigned as: CDR- o (normal); CDR- 0.5 (very mild dementia- mild cognitive impairment), CDR-1 (mild dementia); CDR- 2 (moderate dementia); CDR- 3 (severe dementia)

\section{Rehabilitation in Parkinson's disease}

Modern rehabilitationis holistically oriented, andincludes 
medical, psychological, and social dimensions and it rests on the foundation of teamwork. It is impossible to achieve restitution of activities, social participation, and improving the quality of life in patients with Parkinson's disease through the action of a single profession. In order to optimize the effect of rehabilitation, it is necessary to consolidate a variety of health and non-health professions: physiatrists, physiotherapists, occupational therapists, nurses, psychologists, logopedist, social workers, and institutions that provide and approve the necessary health care.

Rehabilitation is a complex and comprehensive process because the violation of the physical integrity also carries changes in the emotional and social functioning of a person. The occurrence of physical damage may lead to changes in a person's self-perception, professional and family roles, and changes in social status. Priority role of psychologists in the rehabilitation is to assess all mental strengths and potential, so that the patient reaches the maximum, in relation to its current state. An individualized approach to the patient makes it possible to observe all his skills, personality traits, and social functioning, and accordingly schedules an appropriate treatment.

Changes in health status can affect family relationships, work ability and overall quality of life which a patient had before the disease. The role of a social worker is to help the patient and family to adapt to new environmental conditions. Based on interviews (socio-anamnestic interview) with the patient, family and other people in the patient's environment that are important for his recovery, social worker assesses the current needs and with the patient/ family develops a treatment plan.

Although the pharmacological approach remains essential, more systematic reviews and meta-analysis support the hypothesis about the positive effects of physiotherapy and intensive kinesiotherapy on the condition of patients with PD. ${ }^{35,36}$ In their essence, as main ideas, these studies have focused neurorestoration, neuroprotection and slowing the disease progression. ${ }^{37}$

A series of studies over the past decade concluded that the exercises in a structured medical form could slow, stop or even lead to reversion of neurodegenerative processes and encourage neurorestoration of compromised nerve pathways. It is pointed to the possibility that the therapeutic exercise can induce production of glial neurotrophic factor (GDNF) in the substantia nigra where the dopaminergic cells are situated, which is related to neurodegenerative and neuroprotective mechanisms induced by the training. ${ }^{38,39}$

On the other hand, inactivity leads to a possible prodegenerative effect, and physical inactivity is even cited as a possible factor, but also a catalyst in the pathogenesis of Parkinson's disease. ${ }^{40}$ In studies in animal models of Parkinson's disease the beneficial effects of exercise on neuroplasticity are confirmed, even with a neuroprotective effect, with slowing the progression of the disease. ${ }^{41,42}$

The main objective in the rehabilitation of patients with PD is to improve, maintain or delay the deterioration of gait, which in fact implies the possibility for a rapid change in motor activity or motor task (program) when conditions in the external environment change, as well as the possibility for a safe gait during various motor and cognitive tasks. Depending on the phase of PD, design of the gait rehabilitation must take into account the timely different form of progress of motor and nonmotor symptoms of the disease, which affect the gait quality. ${ }^{43}$ Mobility requires the dynamic neural control and the possibility of effective adaptation of movement, control of balance and postural transition during the changes in the environment and specific tasks. Clinical relevance of impaired gait and balance in PD is essential and a key factor which leads to falls, injuries, fractures, and immobility, significantly impairs quality of life, accelerates disease progression and reduces survival.

During the design of the gait rehabilitation in patients with PD, all functional elements that affect mobility must be taken into account. In the gait training, techniques with auditory or visual guides are used, for which researches have shown that they contribute to gait facilitation, and then, if the results of gait pattern are satisfactory, these guides are gradually excluded, with further accentuation of the proprioceptive training which potentiates the sensorimotor integration of the PD patients. They are taught to increase the speed and amplitude of stride in a protective gait pattern. ${ }^{43}$

In recent years, as a part of the rehabilitation concept, aerobic training is more and more recommended, especially the therapeutical training on treadmill tape, which led to improved gait in more treadmill studies in patients with PD. ${ }^{44,45}$ All of these elements are joined by tested concepts with different forms of "guides" techniques that help to keep the proper rhythm and direction of gait, which is of fundamental importance in gait rehabilitation. 
Figure 1. Gait training using visual guides

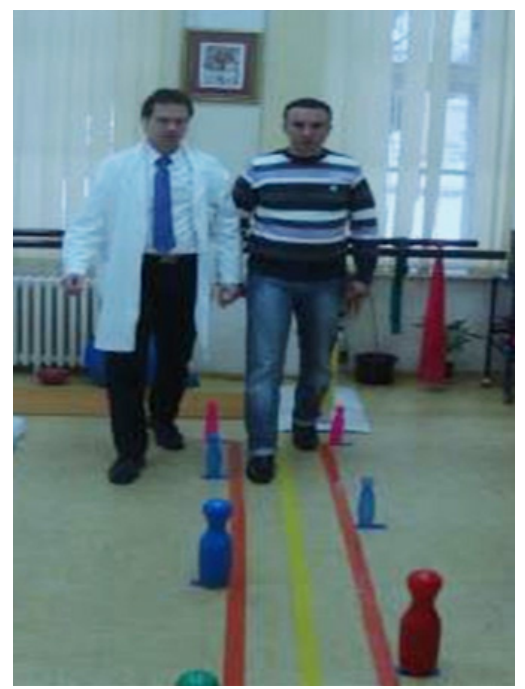

Figure 2. Gait training on a treadmill tape

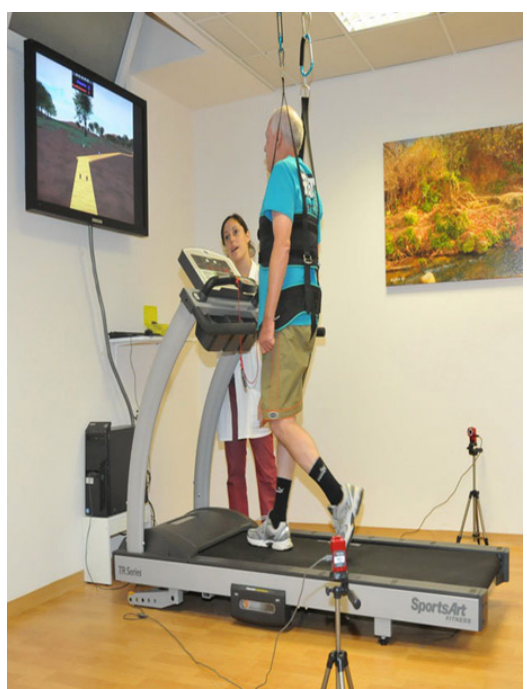

The main method of the rehabilitation of patients with PD is kinesiotherapy in its various forms and in relation to the individual therapeutic target which is based on functional limits. Rehabilitation programs contain kinesiotherapeutic procedures for balance, posture, the range of motions (especially rotatory motions of the trunk), strength, as well as for functionally reduced forms of motion, taking into account the extent and progression of the disease. Functional strength training may be used to increase muscle strength, in particular, extensors of lower limbs and back and the postural control (thoracic stabilizers, hip and knee extensors, anterior tibial muscle and gastrocnemius muscle). Traditional stretching techniques can be used for elongation of shortened flexors of the hip, knee and plantar flexors. Activities for weight shifting provide more opportunities for the integration of functional strength and postural reactions in the movement pattern. ${ }^{46}$

Due to the degenerative nature of the disease, the goals of the program of physical activity are the preservation of muscle function for movements involved in everyday activities. Generally, types of physical activities such as exercises for general coordination and balance are considered, and also relaxation exercises that can reduce muscular incoordination, and tremor. Exercises aimed at maintaining postural strength and flexibility should also be components of the plan and program of the physical activity. ${ }^{47,48}$

Figure 3. Exercises for balance improvement

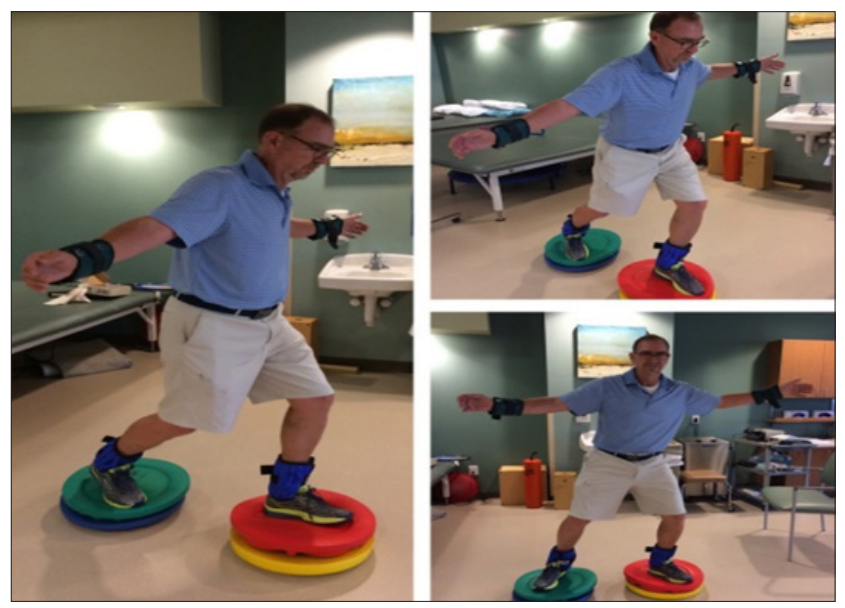

Figure 4. Stretch and strength exercises

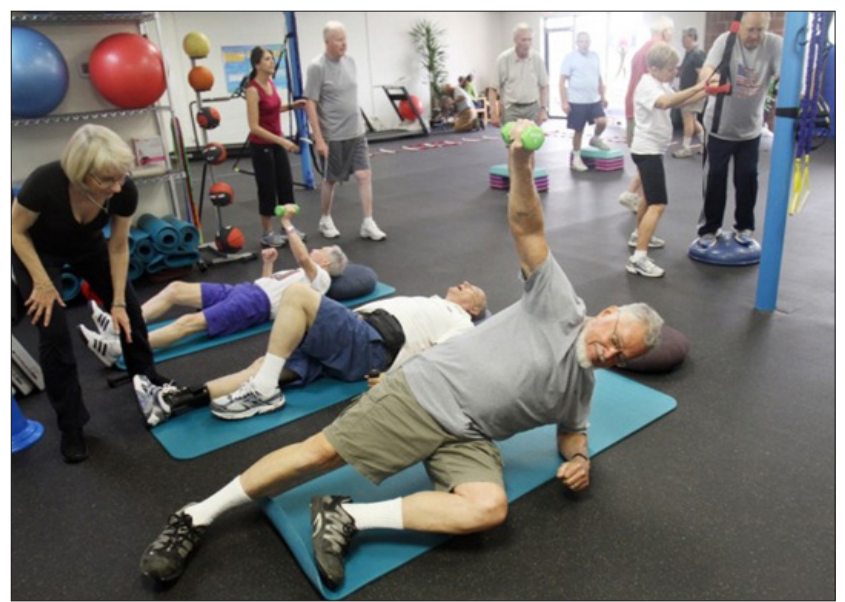


Although kinesiotherapy is the basis of rehabilitation of PD patients, other physical therapy modalities can contribute to alleviating the symptoms of the diseases, such as thermotherapy (to reduce rigor), hydrokinesiotherapy, and electrotherapy.

Transcranial magnetic stimulation (TMS) is a noninvasive neurostimulative and neuromodulatory technique, based on the principle of electromagnetic induction of the electric field in the brain. Short-term, strong magnetic field, emitted above the scalp, passes through the structure of the scalp and induces small, varying electricity in the targeted telencephalic areas. This local electric field can be of sufficient intensity and density to depolarize neurons. When the TMS pulses are applied repetitively (repetitive TMS - rTMS) they can modulate cortical excitability (lowering or raising it), depending on the parameters of the stimulation, even longer than the length of the stimulation.It is believed that rTMS in patients with PD operates in two ways: by increasing cortical excitability of thalamocortical pathways, which is considered to be reduced in PD patients, and modifying the metabolism of a catecholamine in subcortical areas via the cortical stimulation. Besides the effect on the improvement of motor function, it has been shown that rTMS has a good therapeutic the effect on depression, that is present in about 50\% of patients with Parkinson's disease. ${ }^{49}$

An important role in the rehabilitation of these patients also has occupational therapy, with the aim to help the patient to be more independent in activities of daily living. The occupational therapist works with the patient in increasing of the mobility, prevention of falls, transfers, activities in bed, self-care activities (training of feeding, dressing, personal hygiene), overcoming of architectural barriers and performs the advisory work with the patient and family, regarding the adaptation of living space.The aim of kinesiotherapy and occupational therapy is to bring to the maximum independent functioning of the person and minimize the occurrence of complications. The strategy for movement includes launching education and re-education of the person about carrying out activities such as: turning during gait, turning in bed, getting up and going to bed, getting up and sitting down on a chair, reaching for objects etc. It is important to recognize the resulting compensation and act upon it.

Contemporary neurorehabilitation approach emphasizes the concept of a highly individualized structured rehabilitation program that includes diagnostics and rehabilitation of gait with an integrated kinesiotherapeutic program that includes various types of exercises and training whose therapeutic targets are defined by functional limits, for each patient individually.
For each patient, a specific dosage and progression of training are determined, both in quantity and in severity, to overcome challenges of movement in the environment.

In neurodegenerative disorders, all modalities for improving the gait function are essentially a lifelong activity. Therapeutic strategy comes down to the combination of pharmacotherapy and neurorehabilitation methods.

\section{References}

1. Dickson DW. Parkinson's disease and parkinsonism: Neuropathology, Cold Spring Harb Perspect Med. 2012 Aug 1; 2(8): pii:aoog258.

2. Bohlhalter S, Kaegi G. Parkinsonism: heterogeneity of a common neurological syndrome. Swiss Med Wkly, 2011, Nov 1;141:w13293.

3. Hirsch L, Jette N, Frolkis A, Steeves T, Pringsheim T. The incidence of parkinson's disease: A systematic review and meta-analysis. Neuroepidemiology, 2016; 46:292-300.

4. Pringsheim T, Jette N, Frolkis A, Steeves TD. The prevalence of Parkinson's disease: a systematic review and meta-analysis.Mov Disord. 2014;29:1583-90.

5. Poewe W. The natural history of Parkinson's disease. J Neurol 2006; 253(Suppl 7):VII2-6.

6. Charlotte Haaxma CA, Bloem BR, Borm GB, Leendeis KL, Eshuis S, et al. Gender differences in Parkinson's disease,J Neurol Neurosurg Psychiatry. 2007 Aug; 78(8): 819-24.

7. Lang AE, Obeso JA. Time to move beyond nigrostriatal dopamine deficiency in Parkinson's disease. Ann Neurol, 2004; 55:761-5.

8. Braak H, Braak E, Yilmazer D, Shultz C, deVasRA, Jansen EN. Nigral and extranigral pathology inParkinson's disease. J Neurol Transm Suppl 1995; 46: 15-31.

9. McAuley JH. The physiological basis of clinical deficits in Parkinson disease. Prog Neurobiol, 2003; 69(1): 27-48.

10. Volpicelli-Daley LA, Luk KC, Patel TP, Tanik SA, Riddle DM, Stieber A et al. Exogenous a-Synuclein Fibrils Induce Lewy Body Pathology Leading to Synaptic Dysfunction and Neuron Death, Neuron,2011; 72, 1: Pages 57-71.

11. Calne D. A definition of Parkinson's disease. Parkinsonism Relat Disord 2005; 11 (Suppl 1): S39-40.

12. Erro R, Stamelou M. The motor syndrome of Parkinson's disease.Int Rev Neurobiol, 2017;132:25-32.

13. Bonnet AM, Czernecki V. Non-motor symptoms in Parkinson's disease: cognition and behavior. Geriatr Psychol Neuropsychiatr Vieil. 2013 Sep;11(3):295-304.

14. Bassetti CL. Non-motor disturbances in Parkinson's disease. Neurodegener Dis 2011; 8:92-108.

15. Stebbins GT, Goetz CG, Burn DJ, Jankovic J, Khoo TK, Tilley BC. How to identify tremor dominant and postural instability/gait difficulty groups with the movement disorder society unified Parkinson's disease rating scale: 
comparison with the unified Parkinson's disease rating scale. Mov Disord, 2013 May;28(5):668-70.

16. Marras C, Lang A. Parkinson's disease subtypes. J Neurol Neurosurg Psychiatry 2013; 84(4): 409-15.

17. Moustafa AA, Chakravarthy S, Phillips JR, Gupta A, Keri S, Polner B, net al. Motor symptoms in Parkinson's disease: A unified framework, Neurosci Biobehav Rev, 2016 Sep; 68:727-40.

18. Shahed J, Jankovic J. Motor symptoms in Parkinson's disease, Handb Clin Neurol; 83: 2007:329-42.

19. Sapir S, Ramig L, Fox C. Speech and swallowing disorders in Parkinson disease. Curr Opin Otolaryngol Head Neck Surg 2008; 16, 3:205-10.

20. Boonstra TA, van der Kooij H, Munneke M, Bloem BR. Gait disorders and balance disturbances in Parkinson's disease: clinical update and pathophysiology. Curr Opin Neurol 2008; 21:461-71.

21. Schaafsma JD, Giladi N, Balash Y et al. Gait dynamics in Parkinson's disease: relationship to Parkinsonian features, falls and response to levodopa. J Neurol Sci; 2003; 212:4753.

22. Murray MP, Sepic SB, Gardner GM, Downs WJ. Walking patterns of men with parkinsonism. Am J Phys Med, 1978; 57: 278-94.

23. Rosin R, Topka H, Dichgans J. Gait initiation in Parkinson's disease. Mov Disord, 1997;12:682-90.

24. Breniere Y, Do C. Control of gait initiation. J Mot Behav. 1991; 23: 235-40.

25. Burleigh JA, Horak FB, Nutt JG, Obeso JA. Step initiation in Parkinson's disease: Influence of levodopa and external sensory triggers. Mov Disord, 1997;12: 206-15.

26. Morris ME, Lansek R, Matyas TA, Summers JJ. Stridelength regulation in Parkinson's disease. Normalization strategies and underlying mechanisms. Brain, 1996;119:551-68.

27. Thompson $\mathrm{P}$, Marsden CD. Clinical neurological assessment of balance and gait disorders. In: Bronstein A et al, editors. Clinical Disorders of Balance Posture and Gait. London: Arnold, 1996:79-84.

28. Brown P, Steiger M. Basal ganglia gait disorders. In: Bronstein A et al, editors. Balance Posture and Gait. New York: Arnold with co-publishers Oxford University Press, 1996:156-67.

29. Hoehn MM, Yahr MD.Parkinsonism: onset, progression and mortality Neurology. 1967;17:427-42.

30. Fahn S, Elton RL, UPDRS program members. Unified Parkinson's Disease Rating Scale. In: Fahn S, Marsden CD, Goldstein M, Calne DB, editors. Recent Developments in Parkinson's Disease, vol. 2. Florham Park, NJ: Macmillan Healthcare Information, 1987;153-163, 293-304.

31. Hamilton $\mathrm{M}$. The assessment of anxiety states by rating. $\mathrm{Br}$ J Med Psychol 1959; 32(1):50-5.

32. Hamilton M. A rating scale for depression. Neurol, Neurosurg, and Psychiatry 1960;23: 56-62.
33. Folstein MF, Folstein SE, McHugh PR. "Mini-mental state": a practical method for grading the cognitive state of patients for the clinician. J Psychiatr Res 1975;12(3):18998.

34. Morris, JC. The Clinical Dementia Rating (CDR): current version and scoring rules. Neurology 1993; 43(11), 2412-14.

35. Tomlinson CL, Patel S, Meek C, Herd CP, Clarke CE, Stowe $\mathrm{R}$, et al. Physiotherapy versus placebo or no intervention in Parkinson's disease. Cochrane Database Syst Rev 2013 Sep 10;9:CDoo2817.

36. Lima LO, Scianni A, Rodrigues-de-Paula F. Progressive resistance exercise improves strength and physical performance in people with mild to moderate Parkinson's disease: a systematic review J Physiother 2013; 59:7-13.

37. Hirsch MA, Farley BG. Exercise and neuroplasticity in persons living with Parkinson's disease. Eur J Phys Rehabil Med 2009;45:215-29.

38. Cohen AD. Neuroprotective effects of prior limb use in 6-hydroxydopamine-treated rats: possible role of GDNF. J Neurochem 2003;85:299-305.

39. Steiner B. Enriched environment induces cellular plasticity in the adult substantia nigra and improves motor behavior function in the 6-OHDA rat model of Parkinson's disease. 2006;199:291-300.

40. Tillerson JL, Caudle WM, Reverón ME, Miller GW. Exercise induces behavioral recovery and attenuates neurochemical deficits in rodent models of Parkinson's disease. Neuroscience. 2003; 119: 899-911.

41. Fisher BE, Petzinger GM, Nixon K, Hogg E, Bremmer S, Meshul CK, et al. Exercise-induced behavioral recovery and neuroplasticity in the 1-methyl-4-phenyl-1,2,3,6tetrahydropyridine-lesioned mouse basal ganglia. $\mathrm{J}$ Neurosci Res 2004;77:378-90.

42. Maetzler W, Liepelt I, Berg D. Progression of Parkinson's disease in the clinical phase: potential markers. Lancet Neurol 2009;8:1158-11.

43. Spaulding SJ, Barber B, Colby M, Cormack B, Mick T, Jenkins ME. Cueing and gait improvement among people with Parkinson's disease: a meta-analysis.Arch Phys Med Rehabil. 2013; 94: 562-70.

44. Miyai I, Fujimoto Y, Ueda Y, Yamamoto H, Nozaki S, Saito $\mathrm{T}$, et al. Treadmill training with body weight support: its effect on Parkinson's disease. Arch Phys Med Rehabil. 2000; 81: 849-52.

45. Mehrholz J, Kugler J, Storch A, Pohl M, Elsner B, Hirsch K. Treadmill training for patients with Parkinson's disease. Cochrane Database Syst Rev 2015 Aug 22;(8):CDoo7830.

46. Lima LO, Scianni A, Rodrigues-de-Paula F. Progressive resistance exercise improves strength and physical performance in people with mild to moderate Parkinson's disease: a systematic review V. J Physiother 2013; 59:7-13.

47. Hubble RP, Naughton GA, Silburn PA, Cole MH Trunk muscle exercises as a means of improving postural stability in people with Parkinson's disease: a protocol for a 
randomised controlled trial. BMJ Open 2014 Dec 31;4(12).

48. Ramazzina I, Bernazzoli B, Costantino C. Systematic review on strength training in Parkinson's disease: an unsolved question. Clin Interv Aging 2017; 12:619-28.
49. Vadalà M, Vallelunga A, Palmieri L, Palmiesi B, MeralesMedina K, Iennitti T. Mechanisms and therapeutic applications of electromagnetic therapy in Parkinson's disease. Behav Brain Funct 2015; 11: 26.

\section{Značaj rehabilitacije u liječenju pacijenata oboljelih od Parkinsonove bolesti}

\section{SAŽETAK}

Parkinsonova bolest (PB) predstavlja hronično neurodegenerativno oboljenje sa sporo progresivnim tokom, čija je prosječna dužina trajanja oko 15 godina. Karakteriše se akinezijom/bradikinezijom, tremorom, rigiditetom i posturalnom nestabilnošću, sa tim što je za postavljanje dijagnoze ovog sindroma potrebno bar dva od četri znaka. Prisutan je i čitav spektar nemotornih manifestacija (poremećaj raspoloženja, različit stepen kognitivnog deficita, poremećaj spavanja, zamor, autonomna disfunkcija). Patomorfološka osnova ovog sindroma je poremećaj nigrostrijatnih dopaminergičkih mehanizama,metabolička oštećenja, strukturne promjene (hidrocefalus, tumori) ili degenerativni procesi koji zahvataju presinaptičke nigrostrijatne dopaminergičke projekcije ili sam strijatum.Mada je farmakološki pristup i dalje esencijalan, više sistematizovanih pregleda i meta analiza podržava hipotezu o pozitivnim efektima fizioterapije, a unutar nje i intenzivne kineziterapije na stanje bolesnika sa PB.Glavna metoda u rehabilitaciji bolesnika od PB je kineziterapija u svojim različitim formama u odnosu na pojedinačni terapijski cilj koji je zasnovan na funkcionalinim limitima. Rehabilitacioni programi sadrže kineziterapijske procedure za balans, posturu, obim pokreta, naročito onih rotatornih pokreta u trupu, vježbe snage,istezanja kao i vježbe za funkcionalno redukovane obrazce pokreta. Najveći naglasak u procesu rehabilitacije trebao bi biti na reedukaciji hoda koja podrazumijeva optimiziranje iniciranja, brzine i dužine koraka. Cilj kineziterapije i radne terapije je do maksimuma dovesti samostalno funkcionisanje oboljele osobe, a pojavu komplikacija svesti na minimum.

U neurodegenerativnim poremećajima svi modaliteti za poboljšanje funkcije hoda u suštini su doživotna aktivnost. Terapijska strategija se svodi na kombinovanje farmakoterapije i neurorehabilitacionih metoda

Ključne riječi: Parkinsonova bolest, neurorehabilitacija, hod 